\title{
Variation in the persistence of Escherichia coli 0157:H7 in experimentally inoculated 6-week-old conventional lambs
}

\author{
ADRIAN L. COOKSON*§, ANDREW D. WALES†, JOHN M. ROE $\$$, CHRISTINE M. HAYES:, \\ GEOFFREY R. PEARSON† and MARTIN J. WOODWARD*
}

* Department of Bacterial Diseases, Veterinary Laboratories Agency (Weybridge), Woodham Lane, New Haw, Addlestone, Surrey KT15 3NB, †Department of Pathology and Microbiology and \$Department of Clinical Veterinary Science, University of Bristol, Langford, Bristol BS40 5DU

\begin{abstract}
Six-week-old lambs were inoculated orally with $10^{9} \mathrm{cfu}$ of an antibiotic-resistance marked four-strain mixture of enterohaemorrhagic Escherichia coli (EHEC) 0157:H7 to investigate faecal excretion and intestinal colonisation. In the first experiment, three E. coli $\mathrm{O} 157: \mathrm{H} 7$ isolates were not detected in the faeces of any lambs beyond day 8 post inoculation (pi), or from any of the tissues derived from inoculated animals. One strain, $140065 \mathrm{Nal}^{\mathrm{r}}$, was isolated from the caecum and colon of one lamb on day $9 \mathrm{pi}$, from the rectum of another on day $22 \mathrm{pi}$ and persisted in the faeces for up to 28 days pi. All animals remained clinically normal throughout the study period and histological evidence of adhesion of $E$. coli $0157: \mathrm{H} 7$ to the intestinal mucosa was not found. In a separate experiment, four 6-week-old lambs were inoculated orally with $10^{9} \mathrm{cfu}$ of $E$. coli 0157:H7 strain 140065 $\mathrm{Nal}^{\mathrm{r}}$ alone. Faecal samples were positive for this strain until the end of the experiment (day 19 pi). This strain was also recovered from the gastrointestinal tract of lambs on days 6,18 and 19 pi, but was not isolated at day 17 pi. When sampled separately, rectum and terminal colon contents contained higher numbers of the inoculated strain than the intestinal tissue at these sites. Animals inoculated with 0157:H7 strain 140065 Nal ${ }^{\mathrm{r}}$ alone produced soft faeces from day 5 pi onwards. Although attaching and effacing lesions were observed in the caecum, proximal colon and rectum in one animal on day $18 \mathrm{pi}$, the adherent bacteria did not stain with antiserum raised against the 0157 antigen.
\end{abstract}

\section{Introduction}

Enterohaemorrhagic Escherichia coli (EHEC) O157:H7 has become a major concern in the food industry since its association with human disease in the early $1980 \mathrm{~s}$ $[1,2]$. Infection may lead to diarrhoea, but complications such as haemorrhagic colitis and haemolytic uraemic syndrome may also occur [1]. Carriage of the organism may be asymptomatic, and person-to-person

Received 6 Dec. 2001; revised version received 25 June 2002; accepted 25 June 2002.

Corresponding author: Professor M. J. Woodward (e-mail: M.J.Woodward@vla.defra.gsi.gov.uk).

§Present address: AgResearch Ltd, Grasslands Research Centre, Tennent Drive, Private Bag 11008, Palmerston North, New Zealand. transmission is common [3]. Food-borne infection with EHEC O157:H7 is often associated with the consumption of beef (hamburgers and cold cooked meats) or dairy (unpasteurised milk and cheese) products [4] although EHEC have also been isolated from other foods such as unpasteurised apple juice [5] and mayonnaise [6].

The epidemiological link between human disease and consumption of bovine products has indicated that cattle are a primary reservoir for EHEC O157:H7 [4] although recent studies have indicated that sheep are also an animal reservoir [7-13]. Although the mechanisms that mediate persistence within cattle have not been identified, interaction with the host and other bacteria via surface structures may play a role. For example, adhesion of EHEC to epithelial cells is often associated with regions of microvillus effacement where bacteria are intimately attached to the host cell 
surface. The formation of this attaching and effacing (AE) lesion is mediated by secreted and surface arrayed bacterial proteins encoded by a pathogenicity island called the locus for enterocyte effacement (LEE) [14]. Fimbrial expression in vivo by EHEC O157:H7 has not been established [14-17] and expression is not readily observed in vitro [18-20]. Indeed, type 1 fimbriae are not elaborated by E. coli $\mathrm{O} 157: \mathrm{H} 7$ because of a 16-bp deletion within the regulatory region of fimA [19], and curli expression was observed in only $2(4 \%)$ of 49 isolates [20].

Naturally exposed or experimentally inoculated mature cattle may carry EHEC O157:H7 transiently with no clinical signs. Five-day old gnotobiotic calves that had been inoculated orally with $10^{9} \mathrm{cfu}$ of a single EHEC O157:H7 strain remained asymptomatic [21]; however, some weaned calves exhibited a mild transient diarrhoea but there was no histological or immunohistochemical evidence of mucosal adherence or other pathological changes [22]. Epidemiological data indicate that, while certain E. coli serovars such as O26 [23-25] and O118 [26, 27] may cause clinical signs and AE lesion formation, EHEC O157:H7 is only rarely associated with disease in cattle [28].

The importance of intimin, a component of the LEE, to adhesion and formation of O157:H7-associated AE lesions has been demonstrated in both pig and calf models [15, 16, 24, 29-31]. AE lesions were identified in both the small and large intestines of colostrumdeprived 12-36-h old neonatal calves that were inoculated with EHEC O157:H7 (10 $\left.{ }^{10} \mathrm{cfu}\right)$ [29]. AE lesion formation was also observed in the caecum and rectum of weaned (4-month-old) calves inoculated after a period of fasting $[30,32]$.

In sheep inoculated experimentally, E. coli $\mathrm{O} 157: \mathrm{H} 7$ strains were excreted for up to 2 months [33] and were thought to be better adapted to persist in the gastrointestinal tracts than enteropathogenic and enterotoxigenic E. coli. However, the exact mechanism by which colonisation and persistence occurs is not understood. Six-month-old and 6-day-old lambs inoculated with $10^{9} \mathrm{cfu}$ of a four-strain mixture of EHEC O157:H7 remained healthy without diarrhoea $[34,35]$ and, in the older animals, the ability to recover the bacteria from any part of the gastrointestinal tract was limited [34]. Sparse, small, focal lesions, typical of AE E. coli (AEEC), were observed in the caecum of two 6day-old colostrum-fed lambs and in the caecum and rectum of one other [35]. Immunohistochemical staining confirmed the presence of $\mathrm{O} 157$ organisms in the lesions and classical intimate adherence with microvillus effacement was observed by electron microscopy. The present study was designed firstly to test whether older, recently weaned lambs were susceptible to persistent colonisation by EHEC O157:H7 and, secondly, whether any associated pathological changes could be detected.

\section{Materials and methods}

\section{Bacterial strains and inocula}

Human EHEC O157:H7 strains EC157 Str $^{\mathrm{r}}$ (streptomycin resistant) and $140065 \mathrm{Nal}^{\mathrm{r}}$ (nalidixic acid resistant), and bovine EHEC O157:H7 strains 218 Rif $^{\mathrm{r}}$ (rifampicin resistant) and $222 \mathrm{Nal}^{\mathrm{r}} \mathrm{Rif}^{\mathrm{r}}$ have been described previously [34,35]. Strains EC157 and 218 possessed both stx 1 and stx 2 toxins and strains 140065 and 222 possessed stx 2 only. All four strains generated the localised adherence phenotype on HEp-2 tissue culture cells and generated actin re-arrangements characteristic of the $\mathrm{AE}$ lesion, as demonstrated by fluorescence actin staining (FAS) [36]. Inocula were prepared by growing bacteria overnight at $37^{\circ} \mathrm{C}$ in Luria-Bertani (LB) broth. For the four-strain mixed inoculum, samples $(2.5 \mathrm{ml})$ of each of the overnight cultures of EC157 $\mathrm{Str}^{\mathrm{r}}, 140065 \mathrm{Nal}^{\mathrm{r}}, 218 \mathrm{Rif}^{\mathrm{r}}$ and 222 $\mathrm{Nal}^{\mathrm{r}} \mathrm{Rif}^{\mathrm{r}}$ were mixed together and made up to $100 \mathrm{ml}$ with phosphate-buffered saline (PBS, $\mathrm{pH} 7.4$ ). For the single-strain inoculum, a sample $(10 \mathrm{ml})$ of strain $140065 \mathrm{Nal}^{\mathrm{r}}$ was made up to $100 \mathrm{ml}$ with PBS. Therefore, these bacterial suspensions contained $c$. $10^{9} \mathrm{cfu} / 10-\mathrm{ml}$ volume that was used as the inoculum. Samples were serially diluted and spread on LB agar plates with appropriate antibiotic supplements to determine viable counts. Selection for EC157 $\mathrm{Str}^{\mathrm{r}}$, $140065 \mathrm{Nal}^{\mathrm{r}}$, $218 \mathrm{Rif}^{\mathrm{r}}$ and $222 \mathrm{Nal}^{\mathrm{r}} \mathrm{Rif}^{\mathrm{r}}$ from the derived samples was made on CHROMagar O157 (CHROMagar) supplemented with streptomycin $(25 \mu \mathrm{g} / \mathrm{ml})$, nalidixic acid $(15 \mu \mathrm{g} / \mathrm{ml})$, rifampicin $(150 \mu \mathrm{g} / \mathrm{ml})$, or nalidixic acid $(15 \mu \mathrm{g} / \mathrm{ml})$ and rifampicin $(150 \mu \mathrm{g} / \mathrm{ml})$ together.

\section{Animals}

Ten 6-week-old weaned cross-bred lambs were maintained in a paddock. Samples of rectal contents were taken on two separate occasions and were subjected to immunomagnetic separation (IMS) after pre-enrichment in buffered peptone water (BPW) [25, 37]. Washed beads were incubated overnight on CHROMagar $\mathrm{O} 157$ plates to screen for E. coli O157:H7. All animals were confirmed to be free of E. coli $\mathrm{O} 157: \mathrm{H} 7$ by this method before inoculation.

\section{Inoculation and tissue collection}

For the four-strain inoculum, four animals were selected at random, individually tagged with a unique identifier (A-D), sheared on the right flank, and penned together in a biological hazard containment facility. They were given 1 week to adjust to the new environment and were fed a complete pelleted diet with water ad libitum. After 1 week, each animal was inoculated orally with the four-strain mixture of E. coli O157:H7. Animals were observed twice a day and faecal samples from each animal were collected daily for bacteriological analysis. One animal was anaesthetised with intravenous pentobarbitone on each of days 
9, 15, 22 and 29 post inoculation (pi) respectively. Following aseptic preparation of the right flank, a laparotomy was performed and tissue samples comprising rumen, duodenum, jejunum, ileum, caecum, colon (three sites), tonsils, mesenteric lymph nodes, liver, spleen and kidney were collected, by a clean technique, for bacteriological and histological examination. The animal was then killed humanely.

For the single-strain inoculum, four animals $(\mathrm{E}-\mathrm{H})$ were selected and housed as above. After 1 week, each animal was inoculated orally with E. coli $0157: \mathrm{H} 7$ strain $140065 \mathrm{Nal}^{\mathrm{r}}$. Monitoring and faecal sampling were performed as described above. Tissues were sampled under terminal anaesthesia as above from one animal on each of days $6,17,18$ and 19 pi. In addition to the sample sites used for animals A-D, samples of the intrapelvic portion of the rectum and the contents of the distal large intestine were also collected. Two lambs (I and J) were uninoculated controls and tissue samples were collected as above under terminal anaesthesia at 10 weeks of age for histological examination.

All procedures complied with the Animals (Scientific Procedures) Act 1986 and were performed under Home Office Licence 70/4987.

\section{Bacteriological examination}

Samples were analysed immediately after being taken, as follows. Faecal $(1 \mathrm{~g})$ and tissue $(2.5 \mathrm{~g})$ samples were collected, placed in 9-ml and 22.5-ml volumes of BPW respectively and homogenised. A most probable number approach was used to determine, semi-quantitatively, the bacterial count in each sample. Thus, each homogenate was diluted 10 -fold serially in $\mathrm{BPW}$ and then each dilution was incubated for $6 \mathrm{~h}$ at $37^{\circ} \mathrm{C}$ before $1 \mathrm{ml}$ was processed by immunomagnetic separation (IMS). Briefly, $20 \mu \mathrm{l}$ of beads (Dynal) coated in polyclonal antisera raised against the O157 lipopolysaccharide were mixed with the 1-ml sample on a rotator for $30 \mathrm{~min}$ at room temperature. Non-adherent bacteria were removed with three washes of PBSTween $20(0.05 \%)$. For experiment one, the beads were then resuspended in $100 \mu \mathrm{l}$ of PBS ( $\mathrm{pH} 7.4)$ and $25 \mu \mathrm{l}$ were spread on to separate nalidixic acid, rifampicin, streptomycin or nalidixic acid and rifampicin supplemented CHROMagar O157 plates. For experiment two, selection was on CHROMagar O157 plates supplemented with nalidixic acid alone, and the final $100 \mu \mathrm{l}$ of bead suspension were spread on a single plate. The serogroup of lilac-coloured colonies recovered from these experiments was confirmed by O157-specific latex agglutination (Oxoid).

\section{Histological examination}

Tissues were placed in neutral buffered formalin $10 \%$ immediately after excision from the animal and left immersed for at least $24 \mathrm{~h}$ at room temperature. Trimmed tissues were processed routinely and embedded in paraffin wax, and $4-\mu \mathrm{m}$ sections were stained with haematoxylin and eosin $(\mathrm{H})$ for light microscopy. Furthermore, sections of intestinal tissues from lamb $\mathrm{G}$ plus a representative sample of intestinal tissues with loosely adherent luminal bacteria from five other animals and the tonsil tissues from lamb $\mathrm{H}$ were immunostained by an indirect peroxidase-antiperoxidase (PAP) stain as described previously [35]. The primary antiserum was polyclonal and raised against the E. coli $\mathrm{O} 157$ lipopolysaccharide antigen. E. coli $\mathrm{O} 157$ and O26 cultures were formalin-fixed, suspended in agar and then embedded in paraffin wax and sectioned at $4 \mu \mathrm{m}$ These control sections were used to verify the effectiveness and specificity of the immunostaining technique.

\section{Results}

\section{Clinical findings}

Lambs A-D, inoculated with the mixed strains, remained clinically normal throughout the experiment. Their faeces were firm to solid with no evidence of diarrhoea or blood. Lamb E, inoculated with strain $140065 \mathrm{Nal}^{\mathrm{r}}$ alone, had mild diarrhoea at 5 days pi and soft faeces on day 6 pi when it was killed. Lambs F-H, also inoculated with E.coli O157:H7 $140065 \mathrm{Nal}^{\mathrm{r}}$ alone, had soft faeces from day 5 pi until they were killed. There was no loss of appetite or evidence of dehydration in any of the inoculated lambs. The two control lambs were clinically normal at the time they were killed.

\section{Bacteriological findings}

Recovery of the four differentially marked E. coli O157:H7 strains from faecal samples collected from lambs A-D is shown in Fig. 1. Although three of the four strains (EC157 $\mathrm{Str}^{\mathrm{r}}, 218 \mathrm{Rif}^{\mathrm{r}}$ and $222 \mathrm{Nal}^{\mathrm{r}} \mathrm{Rif}^{\mathrm{r}}$ ) were detectable in faecal samples from all lambs for at least the first 4 days pi, they were not isolated from any faecal sample beyond day 9 pi (Fig. 1). Strain 140065 $\mathrm{Nal}^{\mathrm{r}}$ persisted at $c .1 \times 10^{4} \mathrm{cfu} / \mathrm{g}$ of faeces in lamb C (until 21 days pi) and in lamb D (until 28 days pi) but it was not detected in samples from lamb B by day 13 pi (Fig. 1). Of the tissues taken for bacteriological examination from lambs A-D, only 2 of 36 were positive for $\mathrm{O} 157$ bacteria. Strain $140065 \mathrm{Nal}^{\mathrm{r}}$ was detected in the ascending colon $\left(2 \times 10^{2} \mathrm{cfu} / \mathrm{g}\right.$ of tissue) and caecum $\left(2.25 \times 10^{3} \mathrm{cfu} / \mathrm{g}\right.$ of tissue $)$ of lamb A at day 8 pi. Whereas three of the four strains were undetectable by day $9 \mathrm{pi}$, strain $140065 \mathrm{Nal}^{\mathrm{r}}$ persisted for up to 28 days pi. From these data, the criterion for a persistent strain was one that was excreted for $>14$ days pi.

A second study involved the inoculation of four lambs $(\mathrm{E}-\mathrm{H})$ with strain $140065 \mathrm{Nal}^{\mathrm{r}}$ alone. Increased levels 

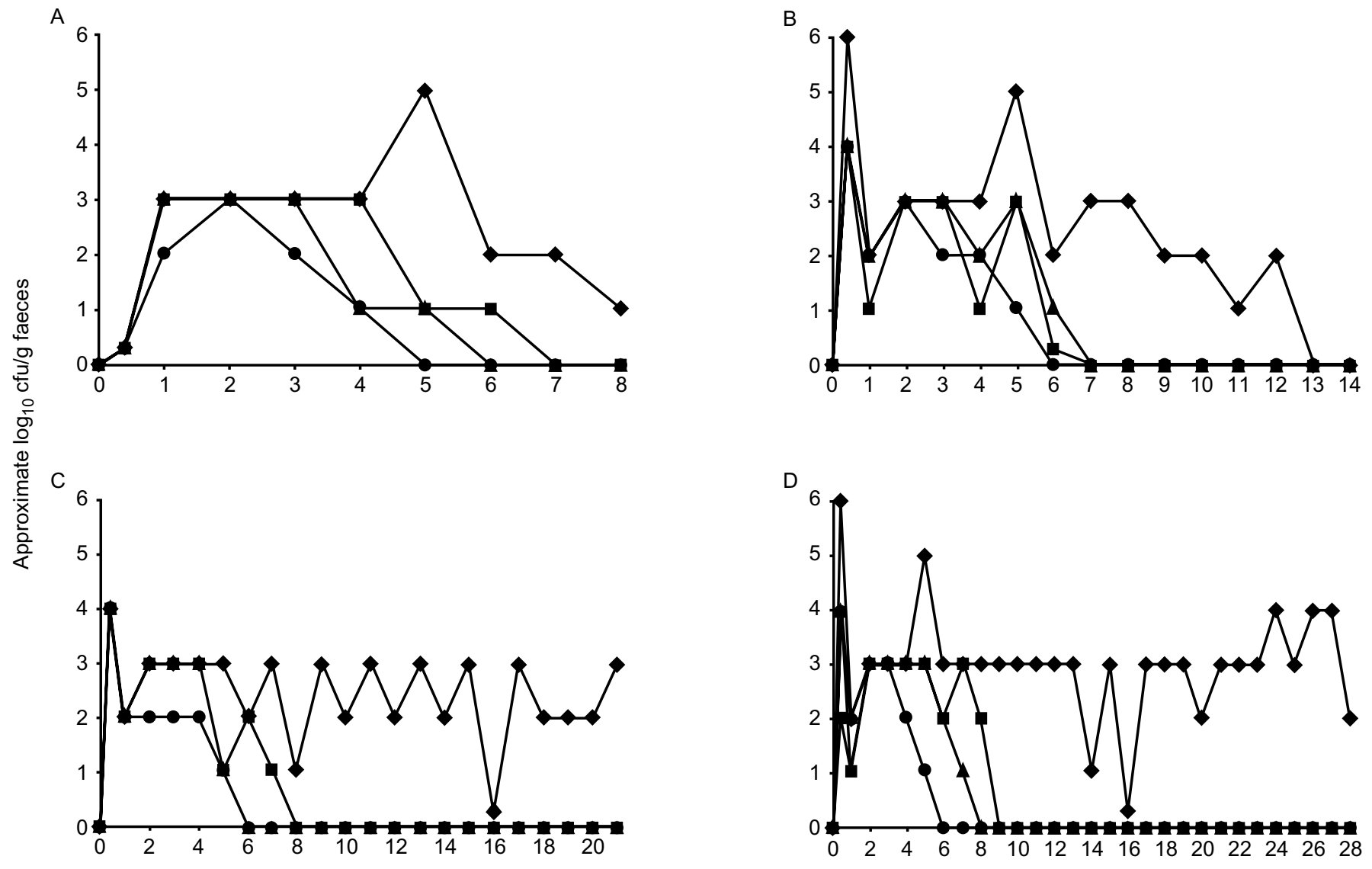

Days after inoculation

Fig. 1. Faecal excretion of E. coli O157:H7 strains from lambs A-D as measured by immunomagnetic separation (IMS) and plating on to CHROMagar O157 supplemented with antibiotics. $\boldsymbol{\square}, \mathrm{EC} 157 \mathrm{Str}^{\mathrm{r}} ; \bullet, 140065 \mathrm{Nal}^{\mathrm{r}} ; \boldsymbol{\Lambda}, 218 \mathrm{Rif}^{\mathrm{r}} ; \boldsymbol{\bullet}, 222 \mathrm{Nal}^{\mathrm{r}} \mathrm{Rif}^{\mathrm{r}}$ 
of shedding were associated with lambs inoculated with strain $140065 \mathrm{Nal}^{\mathrm{r}}$ alone, compared with the same strain in the mixed inoculum (Figs. 1 and 2). Strain $140065 \mathrm{Nal}^{\mathrm{r}}$ was recovered from daily faecal samples from all lambs until day 6 pi, when lamb $\mathrm{E}$ was killed to determine whether the mild diarrhoea and soft faeces were associated with any pathological changes. Bacteria were recovered $\left(10^{2}-10^{4} \mathrm{cfu} / \mathrm{g}\right.$ of tissue $)$ from lamb $\mathrm{E}$ throughout the alimentary tract from rumen to rectum (Table 1). Intermittent excretion of strain $140065 \mathrm{Nal}^{\mathrm{r}}$ was observed in lamb F. It was not isolated from faeces on days $10,11,13$ or $17 \mathrm{pi}$, or from any tissue sites when the animal was killed at day 17 pi (Fig. 2b, Table 1). Bacteria were recovered daily from the faeces of lamb $G$ until it was killed on day 18 pi. On examination of the tissues from this lamb, strain $140065 \mathrm{Nal}^{\mathrm{r}}$ was recovered only from the contents of the terminal colon $\left(<10^{3} \mathrm{cfu} / \mathrm{g}\right.$ tissue $)$. Strain $140065 \mathrm{Nal}^{\mathrm{r}}$ was recovered in high numbers $\left(\geqslant 10^{6} \mathrm{cfu} / \mathrm{g}\right.$ ) from the faeces of lamb $\mathrm{H}$ (Fig. 2d) and was recovered from the ileum through to the rectum in high numbers $\left(10^{2}-10^{6} \mathrm{cfu} / \mathrm{g}\right)$ (Table 1$)$. Higher numbers of bacteria were isolated from both the rectal contents (lambs E and $\mathrm{H}$ ) and terminal colon contents (lambs E, G and H), than were isolated from the intestinal wall samples at the respective sites (Table 1).

\section{Macroscopic pathological findings}

Significant changes were not observed in any animal at any site examined.

\section{Histopathological findings}

With H\&E staining, 16 sections of rumen, 82 sections of small intestine and 219 sections of large intestine were examined from the inoculated animals. Preservation of the intestinal mucosa was generally excellent or good. Mild autolytic changes were present at about half of the sites examined and comprised detachment and loss of epithelium from a minority of villus tips in the small intestine, and small areas of epithelial detachment and single epithelial cell loss at the luminal surface in the large intestine. Four sites in the large intestine demonstrated more marked autolysis in some areas.

In the caecum, proximal loop of the ascending colon and rectum of one animal (lamb G), multiple foci of attaching-effacing bacteria were found. In several large and small intestine sections, loosely adherent luminal contents including bacteria were present on the mucosal surface. AE lesions were not observed in the control animals.

A number of features were noted in tissues from both the control and the inoculated animals. These included small numbers of coccidia in the small and large intestines and slender organisms of spirochaetal morphology in some large intestine crypts. Encysted and luminal nematodes and small crypt abscesses were occasionally present in some sections from inoculated animals. The tonsillar crypts of control and inoculated animals contained adventitious vegetable matter with accompanying bacteria and inflammatory cells. Significant changes were not seen in the liver, kidney or spleen of any animal.

\section{Immunohistochemistry}

The O157 antiserum proved sensitive and specific for E. coli $\mathrm{O} 157$ when used to stain control sections positive for E. coli $\mathrm{O} 157$ and $\mathrm{O} 26$. The immunostained sections from lamb $G$ included $A E$ lesions. Positive staining of bacteria was not observed in any section.

\section{Discussion}

Several studies have established that sheep are a reservoir for $E$. coli $\mathrm{O} 157: \mathrm{H} 7$ [7, 8, 11-13,33]. The present study demonstrated that 6-week-old weaned lambs are a suitable model for investigating the persistence of a mixed strain inoculum of E. coli O157:H7, and that one strain was continually excreted for up to 28 days. The numbers of O157:H7 excreted were determined semi-quantitatively and, although recognised by the authors to be an estimate only, strain $140065 \mathrm{Nal}^{\mathrm{r}}$ was excreted in high numbers $\left(>10^{4} \mathrm{cfu} / \mathrm{g}\right.$ of faeces) consistently in one animal. The limited number of animals and modest scope of bacteriological analysis in each experiment was imposed by the category III containment required. Therefore, the data are not amenable to rigorous statistical analysis. However, the two experiments gave similar persistence data for strain $140065 \mathrm{Nal}^{\mathrm{r}}$ and it is of interest that this persistently excreted strain was derived from a human source with established human pathogenicity (Henry Smith, personal communication). When given a mixed strain inoculum, none of the animals exhibited any clinical symptoms for the duration of the experiment. However, mild diarrhoea or the intermittent production of soft faeces was noted in lambs inoculated with the single strain $140065 \mathrm{Nal}^{\mathrm{r}}$, proven in its persistence. The clinical signs in these lambs may be associated with the four-fold increase in the dose of the persistent 140065 $\mathrm{Nal}^{\mathrm{r}}$ isolate, when compared with the asymptomatic lambs inoculated with the four-strain mixture. No other clinical abnormalities were detected throughout the study.

Previous studies have noted the formation of $\mathrm{AE}$ lesions after experimental inoculation of $0157: \mathrm{H} 7$ into gnotobiotic piglets [31] and neonatal calves $(<36 \mathrm{~h}$ old) [30]. Naturally occurring [38] and experimental [39] non-O157 AE lesions have been reported in neonatal lambs, and E. coli O157:H7 induced very small and sparse AE lesions in 6-day-old colostrum-fed lambs [35]. In 6-month-old sheep, association of $E$. coli O157 with the mucosa was not observed even in an 

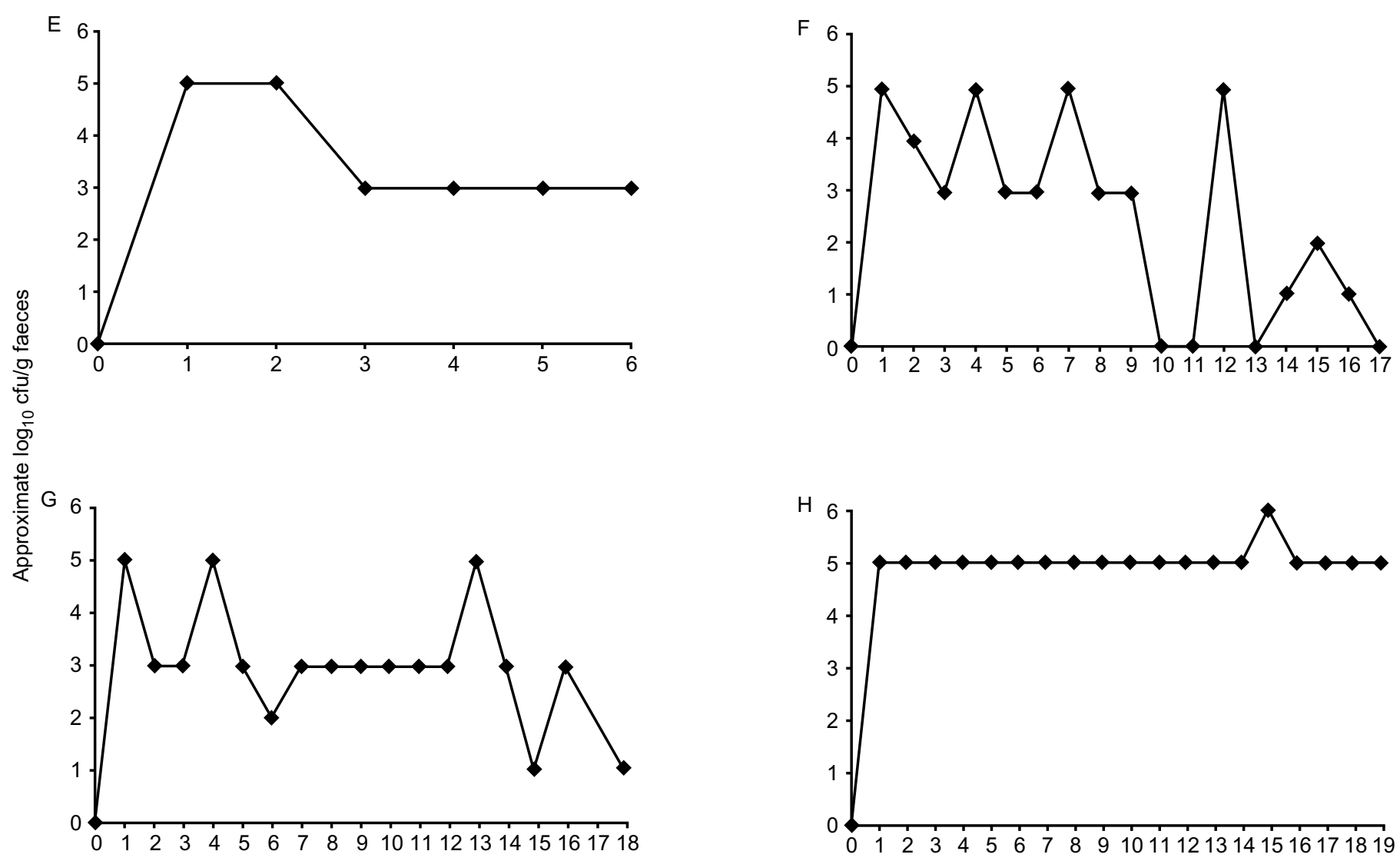

Days after inoculation

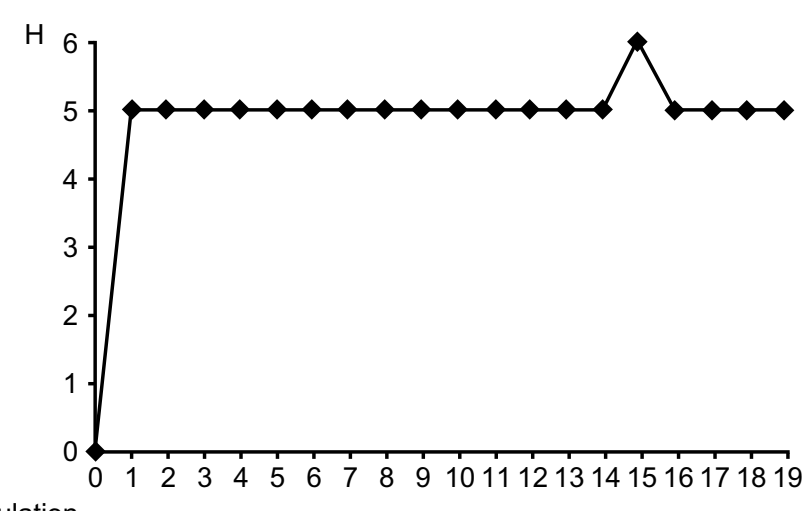

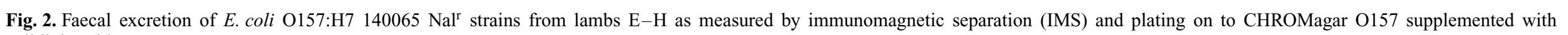
nalidixic acid. 
Table 1. Tissue isolation of $E$. coli $\mathrm{O} 157: \mathrm{H} 7140065$ $\mathrm{Nal}^{\mathrm{r}}$ from lambs $\mathrm{E}-\mathrm{H}$

\begin{tabular}{lcccc}
\hline & \multicolumn{3}{c}{$\begin{array}{c}\text { Isolation* } \\
\end{array}$} & \multicolumn{4}{c}{$\begin{array}{c}\text { of coli } \\
\text { from lamb }\end{array}$} \\
\cline { 2 - 5 } Tissue & $\mathrm{E}$ & $\mathrm{F}$ & $\mathrm{G}$ & $\mathrm{H}$ \\
\hline Tonsil & $\mathrm{ND}$ & $\mathrm{ND}$ & $\mathrm{ND}$ & $\mathrm{ND}$ \\
Rumen & 2 & $\mathrm{ND}$ & $\mathrm{ND}$ & $\mathrm{ND}$ \\
Ileum & 2 & $\mathrm{ND}$ & $\mathrm{ND}$ & 2 \\
Caecum & 2 & $\mathrm{ND}$ & $\mathrm{ND}$ & 6 \\
Ascending colon & 4 & $\mathrm{ND}$ & $\mathrm{ND}$ & 6 \\
Terminal colon & & & & \\
$\quad$ tissue & 2 & $\mathrm{ND}$ & $\mathrm{ND}$ & 4 \\
$\quad$ contents & 4 & $\mathrm{ND}$ & $<3$ & 6 \\
Rectum & & & & \\
$\quad$ tissue & & $\mathrm{ND}$ & $\mathrm{ND}$ & 4 \\
$\quad$ contents & 2 & $\mathrm{ND}$ & $\mathrm{ND}$ & 6 \\
\hline
\end{tabular}

$\mathrm{ND}$, not detected.

${ }^{*}$ By immunomagnetic separation and plating on to CHROMagar O157 supplemented with nalidixic acid.

animal that showed persistent colonisation by the organism [34]. Thus, one aim of the present study was to establish whether AE lesion formation was associated with persistence in lambs of 6-10 weeks of age. Although persistent infection was established in this age group, AE lesions attributable to E. coli O157:H7 were not observed. This is consistent with the findings of other investigators [22, 30, 32] who demonstrated that $\mathrm{AE}$ lesions were detected only in weaned calves which were fasted and then given a high dose inoculum $\left(10^{10} \mathrm{cfu}\right)$ of E. coli $\mathrm{O} 157: \mathrm{H} 7$.

In the present study AE lesions that did not stain with sera raised against the $\mathrm{O} 157$ antigen were detected in one animal. This was an apparently novel finding in weaned lambs and it was important to identify the bacterium associated with these lesions. This is the subject of an accompanying report [40]. As yet, no conclusions may be drawn about the impact that nonO157 lesions may have had upon colonisation by O157:H7.

The absence of O157-associated AE lesions in the present study does not preclude lesion formation as a factor in the persistent colonisation of lambs because any histological examination will, of necessity, examine only a small proportion of the mucosal surface. Indeed, the recent study by Cornick et al. [41] suggested that an intimin-deficient mutant was less able to persist in sheep than the wild-type O157 strain, 86-24. However, these authors did not attempt to detect AE lesions induced by the parent strain or determine the site of colonisation of either parent or mutant. With regard to the in-vitro analysis of the O157 strains used in the study reported here, AE lesions were formed on HEp-2 tissue culture. However, these isolates may have reduced lesion-forming capabilities in vivo when compared with those used in other studies because of possible attenuation by selecting antibiotic-resistant derivatives. Onderdonk et al. [42] showed that E. coli
K12 derivatives that were selected for resistance to nalidixic acid, streptomycin and rifampicin were less effective at colonising the gastrointestinal tract of germ-free mice than wild-type. Moreover, the fitness of the mutants was related to the mutational type, with nalidixic acid-resistant mutants more fit than streptomycin- and then rifampicin-resistant mutants, respectively. It should be borne in mind that $E$. coli $\mathrm{K} 12$ lacks the mechanisms of colonisation associated with $E$. coli $\mathrm{O} 157$ and comparisons of this nature may be misleading. Furthermore, the studies of Cornick and others $[33,41]$ have shown persistent colonisation of streptomycin- and nalidixic acid-resistant double mutants in their studies although the doses to effect this were at least one order of magnitude higher than those used in the studies reported here. Whether the dose compensates for possible attenuation requires examination.

Several surveys have noted a lower prevalence of $\mathrm{O} 157$ in sheep than cattle $[4,7,10,40]$, although the role of the $\mathrm{AE}$ lesion in persistent colonisation of cattle is unknown. It is also possible that isolates of $\mathrm{O} 157: \mathrm{H} 7$ derived from sheep may colonise the ovine gastrointestinal tract more efficiently than the bovine and human isolates that were used in this experiment. Data from the present study are also consistent with the possibility that long-term persistence of E. coli O157:H7 in sheep may be mediated in part by bacterial multiplication within the luminal contents of the gastrointestinal tract rather than adherence. Indeed, at several sites (terminal colon and rectum) of lambs E, G and $\mathrm{H}$, greater numbers (100-fold) of strain 140065 $\mathrm{Nal}^{\mathrm{r}}$ were isolated from luminal contents than from the corresponding intestinal wall samples.

The present study demonstrated considerable differences in the colonisation and persistence of inoculated EHEC O157:H7, both between bacterial strains and between individual animals. No correlation was observed between the strain characteristics determined in vitro and the persistence behaviour observed in vivo. Possible causes of this include competition between strains - although there was no evidence of this for pairs of strains co-inoculated in vitro (data not shown), a differential effect of antibiotic resistance labelling, and inherent strain variability with respect to persistence factors that are currently unknown. One of three animals given the mixed strain inoculum was no longer excreting strain $140065 \mathrm{Nal}^{\mathrm{r}}$ by 14 days pi. Another lamb, which was inoculated with strain $140065 \mathrm{Nal}^{\mathrm{r}}$ only, did not have a detectable level of the inoculum strain in the faeces on days $10,11,13$ and $17 \mathrm{pi}$, despite it being present on the intervening days. This intermittent excretion of 0157:H7 suggests that it may be almost impossible to determine whether cattle or sheep are free of 0157:H7 by current detection methods unless a daily faecal sampling series is performed. However, one lamb consistently shed strain $140065 \mathrm{Nal}^{\mathrm{r}}$ in higher numbers than all the others, which indicates a role for host factors, currently 
unknown, in the level and possibly the duration of shedding of E. coli $\mathrm{O} 157: \mathrm{H} 7$ by sheep.

In the present study, isolation of E. coli $\mathrm{O} 157: \mathrm{H} 7$ from the gastrointestinal tract of animals inoculated with the mixed strain inoculum was rare and limited to the distal regions only. However, when inoculated alone, strain $140065 \mathrm{Nal}^{\mathrm{r}}$ was isolated throughout the gastrointestinal tract of two lambs. Thus, it is possible that there may have been some reduction of colonisation in animals given the mixed strain inoculum rather than the persistent strain $140065 \mathrm{Nal}^{\mathrm{r}}$ alone, but the possible mechanisms for this are unknown.

The present study indicated that the technique of immunomagnetic separation can be used to isolate O157:H7 strains from tissue and faecal samples. This method has been used successfully to isolate EHEC O157:H7 from raw meat products containing $<10 \mathrm{cfu} / \mathrm{g}$ [37]. However, on several occasions strain $140065 \mathrm{Nal}^{\mathrm{r}}$ was undetectable in the intestinal tissue samples when it was still being isolated from faeces. We are unaware of other studies that have used IMS to isolate small numbers of EHEC O157:H7 directly from animal tissue, but loss of beads because of the direct hydrophobic interaction of tissue and beads may reflect the reduced sensitivity of the IMS technique for isolation of E. coli $\mathrm{O} 157$ from tissues and intestinal contents, compared with faeces.

In summary, this study demonstrated the persistence of E. coli $\mathrm{O} 157: \mathrm{H7}$ for up to 28 days in an ovine model with differentially marked isolates. Faecal culture demonstrated that certain O157:H7 strains may be excreted for longer periods than others, and that host factors other than age and diet appear to affect the duration of excretion. Mucosal association by the inoculated strains, including $\mathrm{AE}$ lesions, was not identified in any of the inoculated animals.

We gratefully acknowledge $\mathrm{Mr}$ A. Skuse for expert technical assistance. This work was supported by the Department for Environment, Food and Rural Affairs, UK, through the Food Safety and Zoonoses programme, project OZ0706.

\section{References}

1. Karmali MA, Steele BT, Petric M, Lim C. Sporadic cases of haemolytic-uraemic syndrome associated with faecal cytotoxin and cytotoxin-producing Escherichia coli in stools. Lancet 1983; 1: 619-620.

2. Riley LW, Remis RS, Helgerson SD et al. Hemorrhagic colitis associated with a rare Escherichia coli serotype. $N$ Engl J Med 1983; 308: 681-685.

3. Rowe PC, Orrbine E, Ogborn M et al. Epidemic Escherichia coli $\mathrm{O} 157: \mathrm{H} 7$ gastroenteritis and hemolytic-uremic syndrome in a Canadian Inuit community: intestinal illness in family members as a risk factor. $J$ Pediatr 1994; 124: 21-26.

4. Griffin PM, Tauxe RV. The epidemiology of infections caused by Escherichia coli $\mathrm{O} 157$, other enterohemorrhagic E. coli and the associated hemolytic uremic syndrome. Epidemiol Rev 1991; 13: 60-98.

5. Cody SH, Glynn MK, Farrar JA et al. An outbreak of Escherichia coli O157:H7 infection from unpasteurized com- mercial apple juice. Ann Intern Med 1999; 130: 202-209.

6. Griffin PM. Escherichia coli $\mathrm{O} 157: \mathrm{H} 7$ and other enterohemorrhagic Escherichia coli. In: Blaser M, Smith PD, Ravdin JI, Greenberg HB, Guerrant RL (eds) Infections of the gastrointestinal tract. New York, Raven Press. 1995: 739-761.

7. Chapman PA, Siddons CA, Cerdan Malo AT, Harkin MA. A 1-year study of Escherichia coli 0157 in cattle, sheep, pigs and poultry. Epidemiol Infect 1997; 119: 245-250.

8. Chapman PA, Cerdan-Malo AT, Ellin M, Ashton R, Harkin MA. Escherichia coli $\mathrm{O} 157$ in cattle and sheep at slaughter, on beef and lamb carcasses and in raw beef and lamb products in South Yorkshire, UK. Int J Food Microbiol 2001; 64: 139-150.

9. Fegan N, Desmarchelier P. Shiga toxin-producing Escherichia coli in sheep and pre-slaughter lambs in eastern Australia. Lett Appl Microbiol 1999; 28: 335-339.

10. Heuvelink AE, van den Biggelaar FLAM, de Boer E et al. Isolation and characterization of verocytotoxin-producing Escherichia coli O157 strains from Dutch cattle and sheep. $J$ Clin Microbiol 1998; 36: 878-882.

11. Kudva IT, Hunt CW, Williams CJ, Nance UM, Hovde CJ. Evaluation of dietary influences on Escherichia coli $\mathrm{O} 157: \mathrm{H} 7$ shedding by sheep. Appl Environ Microbiol 1997; 63: 3878-3886.

12. Licence K, Oates KR, Synge BA, Reid TM. An outbreak of E. coli $\mathrm{O} 157$ infection with evidence of spread from animals to man through contamination of a private water supply. Epidemiol Infect 2001; 126: 135-138.

13. Meng J, Zhao S, Doyle MP. Virulence genes of Shiga toxinproducing Escherichia coli isolated from food, animals and humans. Int J Food Microbiol 1998; 45: 229-235.

14. Nataro JP, Kaper JB. Diarrheagenic Escherichia coli. Clin Microbiol Rev 1998; 11: 142-201.

15. Donnenberg MS, Tzipori S, McKee ml, O’Brien AD, Alroy J, Kaper JB. The role of the eae gene of enterohemorrhagic Escherichia coli in intimate attachment in vitro and in the porcine model. J Clin Invest 1993; 92: 1418-1424.

16. McKee ml, Melton-Celsa AR, Moxley RA, Francis DH, O'Brien AD. Enterohemorrhagic Escherichia coli O157:H7 requires intimin to colonize the gnotobiotic pig intestine and to adhere to HEp-2 cells. Infect Immun 1995; 63: 3739-3744.

17. Toth I, Cohen ml, Rumschlag HS et al. Influence of the 60megadalton plasmid on adherence of Escherichia coli $\mathrm{O} 157$ and genetic derivatives. Infect Immun 1990; 58: 1223-1231.

18. Enami M, Nakasone N, Honma Y, Kakinohama S, Kudaka J, Iwanaga M. Expression of type 1 pili is abolished in verotoxinproducing Escherichia coli O157. FEMS Microbiol Lett 1999; 179: 467-472.

19. Roe AJ, Currie C, Smith DGE, Gally DL. Analysis of type 1 fimbriae expression in verotoxigenic Escherichia coli: a comparison between serotypes $\mathrm{O} 157$ and O26. Microbiology 2001; 147: 145-152.

20. Uhlich GA, Keen JE, Elder RO. Mutations in the $\operatorname{csgD}$ promotor associated with variations in curli expression in certain strains of Escherichia coli O157:H7. Appl Environ Microbiol 2001; 67: 2367-2370.

21. Woodward MJ, Gavier-Widen D, McLaren IM, Wray C, Sozmen M, Pearson GR. Infection of gnotobiotic calves with Escherichia coli O157:H7 strain A84. Vet Rec 1999; 144: 466-470.

22. Brown CA, Harmon BG, Zhao T, Doyle MP. Experimental Escherichia coli $\mathrm{O} 157$ carriage in calves. Appl Environ Microbiol 1997; 63: 27-32.

23. Mainil JG, Duchesnes CJ, Whipp SC et al. Shiga-like toxin production and attaching effacing activity of Escherichia coli associated with calf diarrhea. Am $J$ Vet Res 1987; 48: $743-748$.

24. Pearson GR, Bazeley KJ, Jones JR et al. Attaching and effacing lesions in the large intestine of an eight-month-old heifer associated with Escherichia coli O26 infection in a group of animals with dysentery. Vet Rec 1999; 145: 370-373.

25. Wright DJ, Chapman PA, Siddons CA. Immunomagnetic separation as a sensitive method for isolating Escherichia coli O157 from food samples. Epidemiol Infect 1994; 113: 31-39.

26. Chanter N, Morgan JH, Bridger JC, Hall GA, Reynolds DR. Dysentry in gnotobiotic calves caused by atypical Escherichia coli. Vet Rec 1984; 114: 71.

27. Stordeur P, China B, Charlier G, Roels S, Mainil J. Clinical signs, reproduction of attaching/effacing lesions, and enterocyte invasion after oral inoculation of an $\mathrm{O} 118$ enterohaemorrhagic 
Escherichia coli in neonatal calves. Microbes Infect 2000; 2 17-24.

28. Daniel R, Matthews L, Willshaw G. Isolation of E. coli $\mathrm{O} 157$ from a calf with dysentery. Vet Rec 1998; 143: 56.

29. Dean-Nystrom EA, Bosworth BT, Cray WC, Moon HW. Pathogenicity of Escherichia coli $\mathrm{O} 157: \mathrm{H} 7$ in the intestines of neonatal calves. Infect Immun 1997; 65: 1842-1848.

30. Dean-Nystrom EA, Bosworth BT, O'Brien AD, Moon HW. Bovine infection with Escherichia coli O157:H7. In: Stewart CS Flint HJ (eds) Escherichia coli $\mathrm{O} 157$ in farm animals. Wallingford, CABI. 1999: 51-58.

31. Tzipori S, Gunzer F, Donnenberg MS, de Montigny L, Kaper JB, Donohue-Rolfe A. The role of the eaeA gene in diarrhea and neurological complications in a gnotobiotic piglet model of enterohemorrhagic Escherichia coli infection. Infect Immun 1995; 63: 3621-3627.

32. Dean-Nystrom EA, Bosworth BT, Moon HW. Pathogenesis of Escherichia coli O157:H7 in weaned calves. In: Paul PS, Francis DH (eds) Mechanisms in the pathogenesis of enteric diseases 2. New York, Kluwer. 1999: 173-177.

33. Cornick NA, Booher SL, Casey TA, Moon HW. Persistent colonization of sheep by Escherichia coli O157:H7 and other E. coli pathotypes. Appl Environ Microbiol 2000; 66: 4926-4934.

34. Wales $\mathrm{AD}$, Clifton-Hadley FA, Cookson $\mathrm{AL}$ et al. Experimental infection of six-month old lambs with Escherichia coli O157:H7. Vet Rec 2001; 148: 630-631.

35. Wales AD, Pearson GR, Skuse AM et al. Attaching and effacing lesions caused by Escherichia coli O157:H7 in experimentally inoculated neonatal lambs. J Med Microbiol 2001; 50: 752-758.

36. Knutton S, Baldwin T, Williams $\mathrm{PH}$, McNeish AS. Actin accumulation at sites of bacterial adhesion to tissue culture cells: basis of a new diagnostic test for enteropathogenic and enterohemorrhagic Escherichia coli. Infect Immun 1989; 57: 1290-1298.

37. Chapman PA, Wright DJ, Siddons CA. A comparison of immunomagnetic separation and direct culture for the isolation of verocytotoxin-producing Escherichia coli 0157 from bovine faeces. J Med Microbiol 1994; 40: 424-427.

38. Janke BH, Francis DH, Collins JE, Libal MC, Zeman DH, Johnson DD. Attaching and effacing Escherichia coli infections in calves, pigs, lambs and dogs. J Vet Diagn Invest 1989; 1: 6-11.

39. Angus KW, Tzipori S, Gray EW. Intestinal lesions in specificpathogen-free lambs associated with a cryptosporidium from calves with diarrhea. Vet Pathol 1982; 19: 67-78.

40. Cookson AL, Hayes CM, Pearson GR, Roe JM, Wales AD, Woodward MJ. Isolation from a sheep of an attaching and effacing Escherichia coli $\mathrm{O} 115: \mathrm{H}^{-}$with a novel combination of virulence factors. J Med Microbiol 2002; 51: 1041-1049.

41. Cornick NA, Booher SL, Moon HW. Intimin facilitates colonization by Escherichia coli $\mathrm{O} 157: \mathrm{H} 7$ in adult ruminants. Infect Immun 2002; 70: 2704-2707.

42. Onderdonk A, Marshall B, Cisneros, Levy SB. Competition between congenic Escherichia coli $\mathrm{K} 12$ strains in vivo. Infect Immun 1981; 32: 74-79. 